\title{
Artillery in Conjunction with a Force Awaiting Attack
}

\section{Major E. S. May Commanding “T” Battery R.H.A.}

To cite this article: Major E. S. May Commanding "T" Battery R.H.A. (1899) Artillery in Conjunction with a Force Awaiting Attack, Royal United Services Institution. Journal, 43:258, 836-860, DOI: $10.1080 / 03071849909423627$

To link to this article: http://dx.doi.org/10.1080/03071849909423627

册 Published online: 11 Sep 2009.

Submit your article to this journal $\pi$

Џll Article views: 2

Q View related articles $\square$ 


\section{ARTIIIERY IN CONJUNCTION WITH A FORCE AIVAITING ATTACK.}

Sy Mfajor E. S. MAI, Commänding " $T$ " Batlev', R.H.A.

Monday, February 13 th, 1809.

General the Rt. Hon. Sir Redvers H. Bulter, V.C., G.C.B., K.C.MI.G. (Commanding the Aldershot District), in the Chair.

IIHFN, at the very flattering invitation of this Institution, I promised the other day to give a lecture on an Artillery subject, and was left to choose that subject for myself, it was with no small misgivings that I selected that on which I am about to dwell. But we have heard so much of late as to the armament of artillery, as to its organisation, as to its experiences on service, as to its handling in attack, that it seemed only left to me to discuss some features of its employment when circumstances call forth its main energies to ward off, rather than deliver, the great decisive blows of the day. Into the controversy which has always raged, and is still raging, as to whether the improvements in firearms have most favoured attack or defence, I have no idea of entering. It is quite possible to pile argument on argument, so far as mere theory is concerned, in favour of either vicw of the case, and examples from military history can be marshalled in deep battalions to support them. Since the war of 1870 , the success $S$ of the Turks behind their entrenchments in the last Russo-Turkish war, and the universal strides in the manufacture of warlike malériel, have caused many to favour tactics which enable them most fully to utilise cover, while the difficulty even a well-directed fire of shrapnel found in reaching the tribesmen in their strongholds during the late Tirah campaign has given additional weight to their views. Finally, the terrible destruction inflicted on the Dervishes at Omduman must have made many doubt whether it will ever again be possible to take a position in the open when held by troops well trained, well armed; and well led. The Drill-Book says that a superiority of three to one without artillery may do it; but, after reading of the effect of the long-range fire at Omdurman, we may well doubt whether four to one, five to one, $\mathrm{cr}$ six to one will turn the scale under such circumstances.

On the other hand, we must remember that those not fired upon themselves shoot in a very different fashion than they may be expected to when suffering losscs. It is also well, when we draw conclusions from Plerna, to remember that the Russian artillery tactics were then 
contemptible, and that at the Aladja Dagh shelter-trenches and mode:n rifles were no match for well-directed shrapncl. But at that last battle the great result was achieved by artillery in attack. The sp'endid success of the German batteries in 1870 was also gained in that role, and, further away still, the most memorable triumphs of Napoleon recall vast masses of guns flinging their concentrated wcight on a selected spot, and making a breach for the columns of assault. Much of the teaching as regards artillery has accordingly been devoted to guns with an attacking force; there is more fascination about such a rôle, more scope, it may appear, for enterprise, more room for originality. It is time, surels, to give some attention to another side of tactics, and to study what was accomplished by batteries awaiting an attack in position, as, for example, on several occasions during the American war. At Malvern Hill half the casualties on the Confederate side were due to the fearful destruction scattered round by the. Federal guns. It was an efiect unprecedented, I think, up to that time, when round-shot and smooth-bores were not jet obsolete, and modern science had only just begun to affect gunconstruction.

In any case, defensive tactics must ever have a special interest for us, because we have so frequently benefited by them in the past, and shall probably rely largely upon them in the future. Inferiority in numbers often demands the support defensire positions may yield, and we can scarcely hope to fight with the big battalions on our side. For home defence, moreover, where we may find adequate numbers of infantry; it would seem that the support of an efficient field artillery will be lacking, and later on, when I come to define the duties which will fall to batteries, it will be scen how scrious such a deficiercy may prove.

Again, eren if all artillery officers are quite familiar with the various considerations which govern the handling of guns on the defensive, I doubt if all officers of other arms are so well versed in the subject that what I have to say will appear trite and worn threadbare. Yet all officers should completely understand artillery, and assume its dircction with confidence. Properiy speaking, there are no artillery tactics, nor, for the mwter of that, infantry tactics either. We should only know combined tac 's-the rest is drill. In the case of artillery, bullets are fired from big tubes many at a time, and they have an extended range; in the case of infantry, they have a less range, and they fly singly. But both arms utilise the power of fire, ard fire is the determining factor in warfare. If the guns of one side are silenced, it simply means that that side cannot shoot at certain ranges. This disadvantage concerns the force as a whole, not one portion of it; but, if anything, it concems infantry more than artillery, bccause by far the largest portion of all forces is composed of that arm, and the guns are merely the adjuncts and tools utilised in the interests of the infantry to enable it to gain the victory. An arm which prides itseif merely on technical knowledge and skill, and, because of its supposed technicalities, is not confidently handled by an oficer alien to its ranks, will always be imperfectly understood, may even itself become prone to find excuses, and create imyossibilitics. I have 
thought, therefore, of addressing niyse If largely to officers of the other arms, and sincere ly: trust we may subsequently hear some opinions from them.

I may add also that in choosing a tille to this lecture I have been careful to avoid the use of the term "defensive." I did that, perhaps, more in the intercst of the Force as a who'c than in that of the guns. An army may have to take up a position, may strengthen it by entrenchments, and deliberately stand to await an attack. The French did this, for example, at Gravelotte. Again, a force may know that it must hold cut in a certain place for a certain time with a special object in view, as Wellington stood waiting for the coming of the Prussians at Waterloo. But eren in such cases a purely passire altitude should not be the only one contemplated, and still less should an army; coming into collision with arother army when both are in moscment, even if forced to adopt a defensive rôle (as one or other in the nature of things is bound to be), let go the determination to turn the tables when opportunity offers. It might be supposed that artillery, being an arm which can only produce an effect while at rest, and which, to gain the best results, should remain considerable periods in position, would exhibit its highest powers in an attitude of passive defence. It would be a fatal mistake to let that notion get about. Entrenchments and heavy cannon may prove but an illusory sccurity, and the guns must be able to move with the infantry. Certain positions have been surreyed and studied, and a general in the course. of hostilitics may manocurre to occupy them, and if occupied they should be strengthened and fortified, as time permitted. Nevertheless, I trust not a sod will ever be cut, not a spadeful of earth remored, until the circumstances of the moment call for such steps. Otherwise, we may have an incrt occupation of localitics, a helpless clinging to earthworks, in place of a vigorous atlitude of preparation, which signifies that if we wait for our enemy it is only the ketter to spring upen him when the time comes. Our Volunteers, should they ever lave to defend our homes, will, I regret to say, have to rely for support largely on batterics which will scarcely cxhibit proficiency as regards mobility; let us trust they will not imagire that a war of p.ositions is all that they are ever to aspire to. The guns of a force on the defensive should be as prepared to move as those which they opjose, and troops unequal to undertaking the offensive when occasion offers will in the long run fall a prey to thcir antagonists. It is, among other reasons, to remove any misconceptions such as these that $I$ have chosen the subject before us to-day.

We are already well acquainted with the duties of the artillery of the attack, but they may be summed up broadly by saying that to prepare the way for the final assault of the infantry is their most important feature. The enemy is in position in front of it, its target is never a doubtful one, and its whole energies are concentrated on one object alone. The main thing is to get the guns up in good time, and in the later stages of the battle to concentrate their fire on the decisive point. 
Far more dif:cult and complex are the considerations which now govern the handling of guns which await an onset. Let me draw attention to a few.

Concealment of the force of which they form part and of its disposition is a matter of much moment; and many a doubt as to when they should open fire must vex the souls of battery commanders. Likewise, is a well-conccaled position a primary object in these days of smokeless powder, and many a well-proved expedient will no longer ho!d good. Formerly guns were often not seen until they opened fire. It is now next to impossible to see them even after they have done so, if there be bright sunshine, and if the background be not dark. Formerly a dark pinc-wood behind a battery was a distinct advantage, now it is just the reverse, and the bright fashes of the guns against it reveal their presence.

Again, the problem of whether brigade divisions may be broken up or not appears to many to ofier difficulty. We have so much insisted in these last few ycars on the importance of holding that unit together, that the views of even artillery officers have occasionally grown stereotyped concerning it. In the attack, where the object in view is a concentrated effect, you would very rarely divide the three batteries. But when you await attack you usually have in view the object of delaying the enemy as long as possible. Time may send you help, or the attack may develop so slowly that nightfall may bring it to a standstill. IIence you may desire to deceive your opponent as to your strength, and you will certainly want to command all the arenues by which he may advance upon you. Your flanks will rarely or never both rest on natural features, such as will guarantec their sccurity, and a weak flank or flanks must be strengthened by batteries. As I shall presently explain, there are other places also where guns may be necded, but I have, I think, already said enough to show how much an artillery leader with a force awaiting attack may be compelled to disseminate his force, and yet all the time will be planning in his own mind how to keep his firc controlled and directed as much as possible by one will, and how he may oppose the incritable masses of the attack with sinilar masses of guns.

My personal experience has taught me that it is not superfuous to dwell on simple points such as these, although many officers completely understand them. I know that a general last summer said, "I never attempt to do it (that is to say, breal up a brigade division) but I find that my artillery commander raises the strongest possible objections!" Again, I have secn a rear-guard action to gain time undertaken by a division. There were three roads leading right on to the first position it took up. A battery of its brigade-division was told off to command each of the roads, which were so far apart that they could not be seen from one and the same place. Before a subsequent position was reached the three roads had merged into two, and one battery was placed to command one road while two looked after the other. In consequence, the columns of the attack had in both cases to make early deplojments and drive the several batteries aray, before the 
roads could be utilised. The long-range fire of guns had effected its object, the onward march of the attack was much delayed, and the rearguard fulfilled its mission. But I remember that the gunner was blamed because he had broken up his brigade division, as though such action were a species of sacrilege never to be contemplated but with horror, and never to be forgiven. It is little cxperiences, such as these that make me feel that I am not flogging a dead horse when I criticise such views.

The breaking up of a batliry, whether on the defence or not, is, however, a totally different affair, and except under abnormal conditions is never to be thought of, because it absolutely destroys the whole system of training and fire discipline on which the efficiency of our artillery rests. I am quite sure it is not unnecessary to dwell on this minor instance of disseminating guns, for in cren the latest tactical works examples involving the breaking up of batteries are to be found, and indeed the addition of two or three guns to a force appears to be quitc a farourite arrangement.

With these words of preface, I may proceed to discuss more closely the immediate duties of the batteries which await attack. These are usually described as falling within two categories, the "preparatory," and the "main" action. But this preparatory action is not to be confused with that which would very often be confined to the horse artillery batteries with the cavalry, and to those of the corps artillery pushed forward under the protection of squadrons most usually on the flanks with a view to temporarily delaying the enemy's advance, forcing him to disclose his intentions, and preventing him from reconnoitring the dispositions of the defence. It being especially desirable that the manner in which the position is to be occupied should be kept from the enemy as long as possible, it is not advisable to place guns in position during this early stage, although they should be under cover close at hand, ready to come up. Neanwhile the ranges to such places as the hostile guns must occupy are taken. It is almost certain that the guns of the attack when they are deployed will be in superior force, and therefore they should be engaged as they appear, and taken as far as possible in detail. It is also a great object to force an early deployment of the hostile guns, for every time that batteries more they lay themselves open to loss, while if they do not move they cannot support their infantry as they should do.

The defence, therefore, strives to prevent the guns of the attack being at once brought into action at ranges where their effect will probably be considerable; and meanwhile endeavours to show as little as possible of its hand.

The struggle between the two artilleries must, however, sooner or later take place, and it is this which forms the chief part of what is known as the "preparatory" action. In it the advantage of choosing where the main issue is to be fought out, and the power to bring the weight of all its force to bear there, lies with the attack, while on the other side the guns should be better placed, ranges should be known, and but little exposure of men and horses necd be incurred.

But before discussing sundry points in connection with this phase, it is well to say something as to guns in front of the main position. 
Where the ground is open in front of a position, and the advance of the enemy is exposed, advanced posts, even if only to be held by infantry, are not desirable, and they should not be occupied unless they are flanked, and retreat therefrom is covered, by effective artillery or infantry fire from the main position. But, if we may never have to fight in regions such as Great Britain or Ireland, where the country is usually. a good deal wooded and enclosed, we shall frequently have to grapple with the difficulties of such ground at manceurres. Now, at home the country is such that it is often impossible to get a fair ficld of view, and in these cases when some feature of the ground hides the space in front of it from the main position, or if it be such that it offers a point of vantage to the enemy, it may be judicious to hold it strongly, and place guns there, provided always that it possesses a good line of retreat.

Again, an adranced post or position in front of a flank may be of much importance, and a comparatively strong force may be detached to hold it tenaciously. Here the support of guns might sometimes be required, and they might occasionally be so placed as to threaten to enfilade the first line of the hostile attack. Their fire would also draw that of the enemy without exposing the situation of the guns in the main position unnecessarily early. Such a post or position would also cmbarrass the enemy should he attempt any turning movement, because to aroid fire from it he would have to move on a wide arc. It is somelimes said that such posts in front of the centre are useful in facilitating the preparation and issute of counter-attacks, but a post such as I have described would seem a favourable one from which to corer such enterprises, and one flank of the force making the counter-stroke would be protected by it.

Coming to the distribution of guns in the main position, and the choice of sites for them, it is not superfluous to urge that if guns are to fully utilise their range, all ideas such as formerly in the days of smoothbores held sway as to keeping batteries with the units to which they belong, must be abandoned. They must often be handed orer to the will of the supreme authority, to be used for the bencfit of the whole force, and not for that of any particular part of it. "Position is the chief factor in the use of artillery, and its importance increases in compound ratio with the range, accuracy, and power of the arm," as General Tidball, of the United States Army, has well pointed out; the best positions must be allotted to the guns, and they must be placed in them in just such numbers and combinations as circumstances, not organisation, demand. During the impending artillery duel the batteries play a principal part, and at first, thercfore, the dispositions of the infantry must be subordinated to their interests.

It is not, however, until the intention of the enemy to attack is unmistakable that troops need be placed actually on the position, but while they remain under cover preparations in the shape of entrenchments may be made for them. I should say a word, perhaps, as to the value such defences possess for artillery.

Artificial cover does not give a great deal of protection from 
shrapnel bullets to gunners, owing to the angle of descent of the bullets, and the fact that men working a gun cannot stand quite close up to a breastwrits. But it does give a certain amount, and when the ground is favourable may be resorted to. I must point out, however, that while it is not often that it can be utilised in the case of artillery now, it will be still less often that it will be of assistance in the future. For this reason: If you cut away the top surface of the ground, as you do when you make gun-pits, the gun is fired on a substratum of freshly uncovered earth, and this is almost always damp and soft. For drill purposes or at manouvres this does not seem to matter much, the gun is well screened, and the arrangement works admirably. But when service charges and projectiles are in the bore, very whward results soon supervene. The rastly increased recoil drives the wheels decper and deeper into the soil, until they may perhaps sink so much relatively to the point of the trail that the gun cannot be laid or fought; or the rigidity with which the recoil is arrested may be such that rivets, spokes, and plates begin to show signs of giving way. Then wilh difficulty the piece has to be dragged from its place, horses have to be called up to move it, fire is brought to a standstill, and heavy loss is risked. With quick-firing guns these difficulties are all vastly accentuated, for even on moderately hard ground the spades below the gun, on which in one form or other they all rely, dig very inconvenient holes, while on the bottom of a newly dug gun-pit they could rarely be used at all.

Epaulments such as leave the natural surface of the soil as a platform will be better, but they offer a large target and show where the guns are to stand. Thus we see that it will be best for guns to make use of natural corer and the inequalities of the ground as much as possible.

In placing the guns, of course the first consideration is that the ground in front should be swept by fire, and prominent and decisive points must be strongly held rather than an effort made to protect the whole line of front. 'The flanks will often demand the support of batteries. If guns are placed there they may sometimes, although such an arrangement will not often be advantageous, be echeloned back to the rear, so that if the enemy make a flank attack he may more or less expose his own flank to enfilade fire from them.

Perhaps I ought now to enter on an account of what the requirements of a good position for artillery are, but I really think these are largely malters of common sense, and in any case the truth is that it is never in practice a question of picking and choosing. There is usually not a great deal of doubt in the case of a force awaiting attack as to where the position must be, and its size is restricted by the numbers of the force. The features of the ground, woods, or perhaps buildings, further limit the choice of the artillery commander, and it often ends in his having to put up with what is left to him. But if tactical considerations and natural features leave him any choice he must, in addition to the points the Drill-Book expressly dwells upon, think of one which is not mentioned at all, viz., of the facility for ammunition supply which the ground in rear affords. It is no use putting a gun where it can shoot unless you see your way towards giving it something to shoot with. 
There are also one or two counsels of $/ 4$ fection, as I may call them, that I wish to discuss before I go further, ind which will rarely or never be possible to realise.

The text-books tell us that if you place batteries in echelon it renders it difficult for the enemy to range upon them. Theoretically, this sounds very well. But if guns be so placed with troops on either side, their field of fire is restricted much in the same way as is that of a gun which fires through an embrasure. Because, unless you make your echelons stand each at least 100 yards from the other, in these days of decp shrapnel effective$n \geq 5 s$, they will avail little. The batteries, too, which stand back, must usually have a lot of dead ground in front of them, and as the attack advances will have to cease firing in order that they can be brought forward to see their objective. But there is another difficulty too. We in the artillery are pursued by a terrible bugbear called "a danger angle," and an officer often falls an easy prey to irritation when he finds he cannot fire on account of it. For the benefit of the uninitiated. I will define it more exactly. "The line of fire of a gun should not make a smaller angle than $45^{\circ}$ with the line joining its muzzle to the muzzle of the next gun," so speaks "Ficld Artillery Drill." If this particular form of worry be pondered over it will be apparent that since the spaces between batteries must usually be economised to the utmost where sereral are concerned, unless you defy the danger angle, there can rarely or never be any standing in echelon. Consideration as to the danger angle is very necessary, because unless it be kept in view, the premature burst of a shell at practice might mean loss of life. I have never seen it referred to by foreign writers. Perhaps Continental nations do not value conscripts as we do the voluntary soldier, or perhaps the risk is considered worth the advantage gained, or perhaps, which is most likely, we shall all forget about it on service. 'This question does not, however, affect gunners alone, but the infantry too. All the text-books tell us that it is advisable that the artillery in a defensive position should be placed on a line 500 yards or so behind that occupied by the infantry, and sometimes the re-entrants of the position are recommencled for it. The considerations as to danger angles and the restriction of the field of fire involved, which I have just pointed out, should not, however, be left out of sight, and likewise the fact that unless the infantry be pushed well ahead of the guns it will make a double target for the shells of the attack.

A great deal also has been said as to the necessity of not exposing batteries to musketry firc, and for this reason it is ar gued that they must be kept at least the distance I have named behind the firing line of the infantry. I have indicated pretty clearly perhaps already that the lie of the ground and the value of a good ficld of fire narrows this question down a good deal, but as regards the losses involved by musketry it may be pointed out that, when likely to be a long time in position, the teams would be away from the guns under cover, and that ammunition would be supplied from the wagons which would be unhorsed. If placed so as to be as little exposed as possible, the losses amongst the men should not be excessive, because the attacking infantry, when it gets within 800 
yards of the position, will be engaged with infantry, and will be under a heavy fire from that arm, such as will carry away attention from the guns, and militate against accuracy of aim. During the preparatory action, or artillery duel, it will, nevertheless, be advisable to send forward a skirmishing line, which should be placed some 600 yards in front of the guns, in order to prevent any detachment of hostile riflemen establishing themselves within effective rifle range of the batteries.

It is not necessary, nor would it be possible, except on the actual ground, to specify any scheme according to which the batteries should be distributed; but since, if awaiting an attack, you are presumably anxious to gain time, and playing for safety, it will often be wisest to think first of the weak points of the position, and post a certain proportion of guns to cover them. Some will be detailed to provoke and sustain a preliminary combat, while the remainder may be kept under cover in a position of readiness to act. Above all, although, as I have said already, it is not possible usually to avoid some dispersion of batteries, it is necessary to remember that guns should be kept massed in the defence just as theyare in the attack, because effective control and fire discipline are only thus to be obtained.

When the guns are brought up, it should be so as to expose them as little as possible to view, and as plenty of time is available as a rule, they may usually be brought into action by the deliberate method, and often run into their positions by hand. The approach of the enemy's batteries must be closely watched for, and as they deploy a rapid fire must be poured upon them. An intelligent discretion as to how many batteries need open fire must, however, even then be exercised, and as long as it is desired to keep concealed, an unnecessary force, which means an exposure of your dispositions, should not be called into play. Above all is it an error to open on too insignificant a target, such as a comparatively small party of hostile cavalry, or a weak line of skirmishers or scouts.

I think the question of ranges is often a difficult one. In the attack I should be inclined to call 3,000 yards an extreme one, but in the defence the circumstances are different, and when we want to gain time, the loss of a few shells is often repaid, even though small damage may be done by them. Prince Kraft more than once speaks of ranges as distant as 5,400 yards, and his practical experience was such that his words compel our attention. But, except in cases where you command an avenue of approach, and your shells will force a column to deploy, distant artillery fire may mean waste of ammunition, which will be sorely missed perhaps later on in the day.

All the points I have tosched upon require judgment, and it is impossible to do more than invite attention to them, and leave decision to the circumstances of the moment.

When the guns of the attack make their appearance at effective artillery ranges, the superior accuracy which the defending guns should possess must be turned to account in the artillery duel. The fire of the whole of them should be quickly turned on the most exposed of the hostile batteries, and it should be smothered. A similar process 
should be applied to the next, and so on, until the upper hand has been gained. In the case of large forces the general officer commanding the artillery will have to divide the objectire between the brigade divisions which form the mass or masses in which the guns will stand. The hostile line must be divided into sections for this purpose, and each brigade division receive its allotment. Jach brigade division would work on the principle of overwhelming successively portions of its objective. When the task of one brigade division is accomplished, it should be told off to the aid of the one next it, and so on. But there is nothing more difficult than to accomplish in practice what $I$ have thus glibly described. Unless a well-matured system exist, it will not be possible to ensure its success, and, if it be not possible, the artillery fire will be without results.

We have had an interesting object-lesson here lately from the battle of Domokos. The Greek artillery occupied a commanding position from which a perfect view of the Turks in the phin below could be obtained. Fvery hostile gun could be seen, the burst of every shell observed. Not only that, but the Greck guns were so placed that it must have been very difficult for their opponents to see them, and ranging on them was almost impossible. In short, the Greek batteries were fighting under abnormally favourable conditions, their equipment was good, and their training by no means contemptible. Yet they did very little execution. Why? Briefly, because every principle which I have hitherto laid down was violated. In the first place, there was no proper control or direction, and "their batteries were scattered about on knolls and spurs a considerable distance apart, and they worked quite independently:" I quote from the able account of Major C. F. Callwell, R.A., which appeared in the Proceedings of the Artillery' Instilution in October, 1807. Five batteries and three guns of position alone were brought into action, while two or three field batteries were held in reserve after the antiquated fashion in rogue 30 or 40 years ago. Common shell (an obsolete projectile) was chiefly used, and even when an excellent shrapnel shell was fired its management was so little understood that it did no harm. The old idea that common shell was for artillery and shraunel for infantry prevailed on both sides. Yet of so little value is the former projectile that we do not now carry a single round with our batteries. In Thessaly, it is a satisfaction to note, our judgment was fully confirmed, for eren when a common shell burst in a crowd of men and horses it often did no injury whatever. Then again, the duel with the 'Turkish guns began at 3,500 yards, and they never came nearer than 2,000. 'The catalogue of ineptitude is complete, and is equally full on the Turkish side; but we are not now concerned with the attack, so 1 need not further refer to them.

With reference to control as distinguished from direction of fire, I may say that this duty falls to battery commanders, and, always of much importance, will become even more so when our batteries are re-armed with quick-firing equipments. "To silence the guns of the attack is the essential object of the defence," because without the 
stupport of guns no infantry is likely to make a successful assault; and the attacking guns silenced, the defenders' rifles will be sufficient to account for the attacking infantry. Therefore, every round in this ducl should be most carefully and deliberately aimed, and until the range is established no attempt at rapidity should be made, except to take advantage of a temporary and evanescent disadvantageous situation, such as unlimbering for action, in which the attacking batteries may be placed.

But while conlrol may be left to battery officers, diriction of fire should be undertaken by the higher artillery leaders. At one moment it is right to fire on artillery, at another, infantry should be the target. To compel an early deployment from close formations is one object of artillery fire. When the infantry of the attack come within effective range they must be fired on, and yet again when the batteries on that side prepare to move forward to another position will be the time to pour shells upon them. When later the lines of attack become developed, a choice must be exercised as to the line which is to be made the target. It is impossible to lay down hard and fast rules on these subjects; one line may offer a more tempting target than another, but the one which is the most dangerous is the one usually to lay upon. - There are, perhaps, two principles which however will never vary. When artillery is awaiting attack the first thought of its commander after the fight has opened should be, Where will the enemy's batteries move to next?. It will often be easy enough to answer this question, and every preparation should be made to make the change of position perilous. S:condly-and I may explain that, although it may appear contradictory to something I have just said, it is not really so, because in practice a considerable space of time will separate the appearance of the hostile batteries and their infantry--when the infantry do advance to the attack, all the guns of the defence must turn upon it. It is infantry which win victories, and it is the infantry which must be prevented from getting to decisive musketry range.

In this connection we may note how much the long range of rilled guns has accentuated the importance of fire direction. Formerly there was little choice, and men fired at what was opposite to them and immediately in their view; now there is room for considerable selection, and time to make a judicious one, while stratagem can be exhibited also.

It is one of the advantages of the artillery of the defence that it need not move in the main position, whereas that of the attack must manceure. And it may be well to take advantage of this source of its strength. For example, if the fire of the attack begin to show a decided superiority, the guns of the defence may ccase firing, in the hope that their opponents will proceed, as under certain circumstances they frequently will, to move forward to a fresh position. Then it may be possible to take their batteries at a disadvantage while in movement, and make them pay dearly for imagining they had gained a permanent and complete mastery. We know that the experiences of the artillery of the German Guard Corps at Sedan show that one side ceasing fire will often ' $c_{a}$ :Ise the other to do so, and when the German gunners were told to "stand fast" on that occasion, in order that the commanding officers might look over and correct the laying, the French ceased firing too. 
But it may often be wise to withdraw from the artillery duel simply to economise men and ammunition. It may, for instance, become apparent that, if you continue the struggle, your batteries are bound to be completely knocked out, and then there will be no artillery fire to meet the hostile infantry. In that case the guns may either be withdrawn a little way bchind the crest, or, what will perhaps more often be feasible, may be left in position but their detachments withdrawn and placed under shelter.

The actual guns are practically none the worse for being fired upon by shrapnel, even if the encmy, which is scarcely likely, sliould continue to fire on them, and the gunners can come up and mant them again when the infantry of the attack is fairly committed to an advance.

There are excellent examples of a correct and scientific handling of artillery to be culled from some of the battles during the American War of Secession. We hardly hear as much as we ought to do of General H. T. Hunt, who, more than once, displayed something akin to genius in command of the Federal artiller;, but we may learn lessons from him even though his deedis belong to a fast-vanishing epoch.

At Malvern Hill, a sanguinary battle fought in front of Richmond, July 1st, 1862, the power of massed batteries in the defence of a position is splendidly exhibited ; but it is to Gettysburg, fought a year later, that we must turn for the best illustration of the system of temporarily withdrawing guns with which I am acquainted.

Iee had entrusted to Pickett's division the duty of making the great assault on the Federal position. Some 150 guns prepared the way for that celebrated charge, and the Federals, hampered by want of room, could only place about 80 guns in position on the heights opposite. 'The tremendous cannonade began about 1 o'clock, and two hours later General Hunt, wishing to preserve as many guns as possible intact, and to husband ammunition to meet the incritable assault, withdrew 18 guns, and ordered the Federal artillery to cease firing. The mancuvre quite deceived Alexander, who commanded the Confederate artillery. He sent back to Longstreet, to whose corps Pickett's division belonged, to say that he had silenced the hostile guns, and that the moment for the assault had come. Mcanwhile Hunt refilled his limber boxes and refitted his damaged batteries. When the Confederate infantry came on, the empty positions burst forth in a fresh and unexpected eruption of artillery fire. The Confederate artillery was disregarded, and every round was aimed at Pickett's battalions alone. On and on that gallant infantry swept, until it disappeared in the smoke of the guns in front. For five minutes it attempted to make headway amongst that smoke. Then a few disorganised stragglers began to emerge and fall back, more followed, soon the closed bodies began to melt array, and Lce, who was watching it from Alexander's guns, knew that such an army as he could scarcely hope to lead again was broken.

Now, perhaps, I may touch upon quite a new idea which Colenel Wille, the well-known Swiss authority on artillery, has lately put forward. He apparently seems to think that if the two artillerics engage in a vol. XLIII. 
prolonged combat, and the infantry defer its adrance until one has got the upper hand, so much precious time will have been wasted, that none in which to win a battle will remain. Therefore, his view is that the artillery of the attack should devote its main energies to shaking the infantry of the defence, and that it will be a mistake for it to suppose that it is a paramount object for it to silence the guns opposed to it, and that only when this part of its task has been accomplished should it turn its attention to the infantry. He goes on to add that in his view it is best to hold the main. body of the artillery of the attack under cover until the infantry is ready to deploy into attack formation, and then lit the batteries come up fresh. To distract the attention of the defence and draw as much of its artillery fire as possible, some batteries of the attack might be deployed at an earlier stage. These ideas do not appear to me sound, and seem to suggest a return to the old-fashioned reserve of guns which Napoleon brought up to prepare the way for a decisive stroke, a system which does not turn the powers of modern guns to full account. I merely mention them to show how widely some authorities may differ from the usually accepted principles of the day; and also because it is certainly a fact that we do not yet know what effect the intervention of a completely fresh mass of artillery may not mean in a modern battle. Such suggestions as Wille's "be for thoughts," even though we may not approve of them.

Hitherto I have not said much with regard to manceurring on the part of the guns of the defence. It is by no means, however, a matter of which we should let ourselves lose sight. It is with the counter-stroke that the defence breaks its fetters, but a counter-stroke unsupported by artillery fire will never have a permanent infuence on the fortunes of the day. At our mancuvres we rarely sec such an enterprise undertaken, because the fight progresses so rapidly that it is usually brought to a close before there is time to plan and develop it. But at foreign manœuvres counter-attacks are faniliar occurrences. I do not refer to the small local affairs which are perhaps sometimes carried to an excess over the water, but to those on a large scale planned and carried-through by the higher leaders. It is a difficult matter for a man to rapidly grasp the situation, and make up his mind with such prompt decision as will alone seize an opening in the course of a battle. Especially is it so, if he be the weaker, and has in consequence at first been forced to assume a defensive role. Yet Vellington was accustomed by the force of circumstances most often to fight on the defensive, and he won Salamanca by a most brilliant counter-attack, and indeed nerer failed to take the offensive at some part or other of all his battles. But he supported his counter-strokes with artillery, and twelve guns went forward with Pakenham's division, and materially contributed to the success of Salamanca. Marmont's guns similarly assisted the turning of the tables at Marengo, and at Austerliz Napoleon gave the impetus of artillery to his blow. On the other hand, the French counter-attacks at Wörth died away, because not on an adequate scale, and because unbacked by batteries. When a counter-attack aiming at important results is launched, 
guns must nearly always go with it. Otherwise their fire will become masked at a critical moment, and the infantry will feel the absence of the support their sound close at hand invariably lends. It may be necessary, therefore, to shift guns from the main position during the course of battle, and we have no reason to suppose that such an operation will be impossible in the future. Guns may be run back and limbered up behind the crest in many situations, and thus the exposure of the teams when limbering up may be avoided; while we know that the German balteries were able to accomplish it in the kattles round Metz and at Sedan.

On the 10th of September, 1897, at the French mancurres, I saw a very striking example of a large counter-attack, brilliantly conceived and admirably carried out by a division of the Southern Army on the troops holding the chateau and park of. Villers-au-Flos. On that occasion the two horse artillery batteries of the cavalry division, which was halted behind General Kessler's left fank, were sent forward to co-operate with the other guns of the division. But the moment the counter-stroke had exhausted itself, these batturies were recalled to their special duties, and a very short time afterwards were, as a matter of fact, engaged in a great cavalry and horse-artillery action. I thought the manner in which these guns joined in that counter-attack was admirable, but I made a mental note, too, that if the batterics with our cavalry divisions should thus be temporarily employed, the French system, by which they were again placed entirely at the disposal of the cavalry general, should also be imitated.

A point about which there is sometimes a little misunderstanding occurs with reference to guns retiring. In certain defensive actions of course their duty is clear, and they simply stand à l'outrance, and possibly are sacrificed. But it is a rule that on all occasions guns are not to retire without orders from the supreme authority. The rule should be most rigidly adhered to, for nothing may have a more pernicious effect on the course of a battle than the premature or inopportune withdrawal of guns.. On the other hand, when an uncompromising and passive resistance is not intended, guns may be left behind unnecessarily, and will either have to be extricated with difficulty and loss or abandoned. A general must remeniber, therefore, that unless he has agreed beforehand to trust to his artillery leader's discretion, he must direct the movements of the guns in this respect himself. I do not, of course, here refer to a rear-guard action in which a small force of infantry, or cavalry and horse artillery is engaged. Then, it seems to me, that the gunner must often be trusted with and take the whole responsibility when he is separated from his chief. The Drill-Book, however, has no saving clause in it such as this, jet I imagine that it is not intended to be taken so rigidly as it reads.

In conclusion, a few words on ammunition supply will not be out of place.

It may at first sight secm that the provision of ammunition will be easier for the force that is at rest than for that moving to the attack. A 3 D 2 
force pushing forward, as it approaches its enemy, usually prolongs its lines of communication, and at the moment it halts for a battle has often stretched the channel it is fed and supplied through to its fullest extent. The slowly moving ammunition columns and parks have to be urged onward on roads always crowded and often bad, and long distances may. sometimes separate the guns from the reservoirs whence they draw their vitality. On the other hand, it may be imagined that these reservoirs in the case of the defence may be pushed up beforchand close to the line of battle, and that comparatively small hindrances need obstruct the flow from them. But a force does not often stand to fight with the possibility of a retreat being absolutely eliminated from its leader's mind. And in the latter eventuality the communications to the rear must be as clear as possible for the uninterrupted retreat of the fighting portion of the force. Ammunition columns or parks and other impedimenta should encumber them as little as may be. A force retreating is doubling back on, while a force adrancing is freeing itself from, its own encumbrances. In the one case we have to fear over-compression, in the other over-extension. This is why ammunition supply is by no means so simple a problem for a force on the defensive as might be thought; and unless as many as possible of the $\checkmark$ agons of the ammunition columns be got rid of early in the day, a retreat $r$ aymean the loss of a great deal of ammunition, or may be greatly hampered by the congested state of the roads. It may therefore be well to empty the three $\mathrm{A}$. and S. gun ammunition wagons of the column first, by making a sort of temporary expense magazine close to the batteries from which the guns would draw in the commencement. 'These empty $\lambda$. and S. wagons might then be early sent away to be filied up or replaced at the ammunition park or advanced depôt, as the case might be. Artificial cover could usually be extemporised, and the ammunition protected from wet. By this means the immediate battery reserve would be kept intact as long as possible and the danger of the batteries running short of shells wcll-righ obviated.

The carrying out of any expedients such as I have suggested must, however, be left to circumstances. All that can be done on paper is to indicate and suggest a method of action suitable only for batteries in a defensive position. But a reference to ammunition supply opens up the question in a more general form. In view of the probable expenditure of ammunition in the future it seems to me that we have lere a branch of tactics to which more attention should be given. It is a very pressing matter to my mind, not so much because improved manufacture has given unusual facilities to shooting, and that it is easier, and will be even easier still, to get rid of ammunition in the future than it has been hitherto. There is a danger here no doubt, but it is one which can be counteracted by fire discipline, and I have no fears but that however rapidly it may be possible to shoot with a quick-firing gun our officers will be able to completely control their fire. But where both sides are equally vell armed, and where guns have an immense range, battles may begin earlier and may be more protracted than-heretofore. It has often happened eren with smooth-bored firearms that a battle lasted more than one day. 
It will very likely be that in future such long-drawn-out struggles will become more common; there will at least often be a possibility that one day will not yield a decisive result, and we must be prepared for stuch an eventuality. Therefore, allowing for complete fire control, it still seems that the consumption of ammunition will be greater, and the necessity for a speedy and safe renewal of it will be more imperative than our past experience has taught us. We want, therefore, not only a well-thought-out system of supply, but we should make officers of all arms familiar with it by practically secing it at work in the field: And that I rcgret to say is exactly what we do not do. Theoretically, we have now got the system, and the latest edition of "War Establishments" shows us how our ammunition columns are composed. But at the recent manouvres they were very inadequately represented, and no ammunition wagons accompanied the guns; except one per battery, which was valueless for instructional purposes. Ammunition supply from the battery wagons to the guns is practised during the drill season at our larger stations, and when a brigade division is carrying it out, the sight is a most instructive one. No one who has seen it can fail to realise what it implies, and what activity would be taking place behind a great mass of several batteries in position when drawing on their wagons for ammunition, as they would always be doing in a defensive action. Until the whole system is actually seen ir full operation officers do not appreciate the necessity that a position should have considerable depth, and that artillery in action takes up far more room than that which is occupied longitudinally by the guns. Again, the length occupied in column of route by a battery accompanied as it would be on service by its wagons is just clouble what it is without them, and to arrange the order of march for a wagonless artillery is poor practice for staff officers, and engenders false notions as to time and space. For all these reasons, but above all perhaps to give the other arms correct. ideas as to needs and requirements of artillery, a great effort should be made to represent our wagons and ammunition columns more realistically at mancuvres.

It is, I presume, a matter of money-everything comes down to that in the long run-but if money is not to be had for the purpose, we must turn what we have to dispose of to better account. The policy of breaking up batteries to make ammunition columns, or provide borses for wagons for others, is a hateful one. It disgusts officers and men perhaps more than anything else, and, moreover, it sacrifices during the whole manceuvres the training of one lot of officers and men in their most important duties for the benefit of another. I sincerely trust that we may. not sce any expedients of this hind adopted. It would be, in my opinion. infinitely better to put all the artillery in camp on one side for one fight, or perhaps two at each series of mancuvres. 'The side which had the double lot of guns might then attack the other which would represent a marlied enemy, and the additional batteries would park their guns and use their limbers to represent the wagons of the guns in action, while a concentration of all the wagons (supposing each battery at manouvres to have one wagon with it as was the case this year) would pretty well make 
up a complete ammunition column. If another day could be spared to repeat the process, with the forces playing reversed rolles, both sides would se - te artillery of an army working far more nearly under service conditions than we have ever seen it jet at either ficld days or mancuvres.

No doubt such an arrangement would not be an ideal one, and no doubt we should hear murmurs. I am sure I should hate it the day my battery was playing the part of the loader at the covert side, but all the same I believe it would be beneficial, and it would be better to have such a system than nothing.

But that by some means or other we should practise the supply of ammunition and accustom men to regard it as a first consideration when they make their dispositions is, I am surc, essential, and, as I have shown, the problem is more difficult when on the defensive than when in the attack.

As regards how guns should be retired, should a retreat. be ordered, it is scarcely necessary here to discuss, nor need I enlarge on the tactics considered in the Drill-Booksunder the heading of a "Rear-guard Action," but in bringing a lecture on artillery with a force awaiting attack- to a conclusion, I may perhaps most fitly do so by saying that when the force stands up deliberately to fight, the retirement of the guns is about the last contingency which is to be provided for. An unflinching front may turn the scale eren when things look blackest, while to be captured when in flight is the worst fate that can befall a battery.

General E. F. Cuarsus, C.B., R.A. (Commanding Scottish District):-The only occasion I remember in which guns were placed in a position of defence such as the lecturer has outlined was in the campaign of 1866 , when the artillery at Chlum, during the battle of Königgrätz, held the position for sone hours. I saw the position a few days afterwards, and I recollect ranges of all the positions were very carefully marked, and the battery positions were clearly defined at the time. Major May has laid stress on guns not having to retire. In that position, and in any other position held purely on the defensive, it must, I think, involve a retreat. If I remember rightly, the Austrians lost very few of their guns, because they bad carefully considered the methods of retreat; they had worked them all out, and their staff were prepared to handle the guns in retirement after the action. Of course, the position was turned by the Crown Prince moving nearer Königgritz, when Chlum had to be abandoned. The whole foree had to go back without any consideration as to what the artillery would do. A general retirement was ordered by Benedek, and the guns were withdrawn. In $m y$ opinion, we shall always have to consider a possible retirement from any defensive position that might be taken up.

The Charkmax (General Sir Redvers Buller):-If no infantry offecr wishes to speak, I should like to throw myself in the breacl. It is rather difficult to deal with the paper, as the nuthor treats of two distinct phases of war, and $t$ iose I think he has rather confused together. There is the case of a force wich deliberately elects to commence the attack by adopting a defensive róle, probably because its infantry is not all up or because it is a weaker force, and there is the case of a force which is placed in a defensive position beyond which it does not mean to advance. I think the second case I would rather leave out of consideration to-day, and deal only with the first, which I fancy is the one that Major May is more immediately referring to. It seems to me that the real question which must settle the distribution of the artillery is that the officer commanding the force must make up his mind at once how he is likely to be attacked, and the distribution of the positions to be occupied by his artillery- 
must be from the commencement subordinate to the answer he gives to that question, and to the corollary to it, that if he stands to be attacked he will not win the battle unless he has in his mind some effective counter-stroke. His own idea with regard to where he is likely to be attacked and his plan for the counter-stroke he intends afterwards must govern to a great extent the positions which he assigns to his artillery. I was reading a week or two ago a very interesting book which has just been published, called "A Lad in the Peninsular War," in which is deseribed how in moving out from Corunna Sir John Moore worked out his plans to stop Soult. The author says that his regiment was at first in reserve, but only for a short time, while Sir John Noore was making up his mind which was the part of his line most likely to be attacked, and that Sir John lnowing that he had one of the most able of the French marshals against him, decided that he would be attacked in exactly the same way as he would bave altaclied had he been on the French side. He was right, and his whole dispositions for the day were made really with reference to the actual attack. (I think we all believe that had he lived his dispositions would have been completely successful.) It seems to me also that in laying down rules for where artillery is to be or how guns are to be massed or divided, we must be guided by the nature of the ground that is occupied by the defending force. The question of dead ground is, in defence, nost impo:tant, and if you have much dead ground in front of any place that offers great facilities for the massing of a large number of guns I would say beware! If you so place guns that the other infantry are able to get within effective distance of them, and then be perfectly safe from their fire, your defensive position will be in far more danger than if you hand seattered $y$ our guns and arranged to fank this dead ground and keep it underfire. I quite agree that in a sense the arillery and infantry are one, and that their combined action in war nay be considered as if they, were only one arm. It is most important, however, to stop the actual infantry attack, and I question if in defence it is nearly so important to enter into an artillery duel as it is in offence, when you must gain time for your infantry 10 cieploy and their supports to get into proper position, and, if you can, you should occupy the enemy's artillery while they are doing this. I doubt myself if the great stress which the lecturer has laid on the necessity of masșing guns and destroying the artillery of the effence is of the same importance as destroying the altacking infantry, which, to win the battle, must come in front of their guns. That I believe should be the main duty of the artillery of defence. I offer these remarks as an infantry offect, the infantry officers having been challenged to give an opinition.

Major MaY, in replying, said:-With regard to what fell from General Chapman, with reference to due preparation for the retirement of artillery being necessary, and the example he quoted from the campaign of 1866 , the dustrians certainly had much cause for satisfaction as regards the manner their artillery was handled on many. occasions during that disastrous war. The Austrian batteries too have prided themselves very much on the devotion exhibited by the guns which covered the retreat of the rest of the army at Sadowa, and the conduct of some of them on that day has become celebrated. Some critics have, however, not failed to assert, and, I think, perhaps, with some truth, that a great deal of the kudos they gained was perbaps hardly so well deserved as might at first sight appear, because, bravely as the gunners stood their ground, and unhesitatingly as they sacrificed themselves, those batteries could not help themselves, and did not retire because they could not. General Chapman does not seem to take the same view as these critics; but, on the other hand, it is to be renembered that if the artillery is not to stand firm, the other arms will not be able to get away. But when I spoke in my lecture as I did, I did not mean that you were never to have in your mind some idea of retiring, and some general seheme as to how the retirement of your artillery was to be carried out. I certainly do not recommend the unnecessary sacrifice of guns, but there were so 
many points to touch upon that I really had not tine in the hour to go closely into all of them. A good deal of the question of how to retire artillery comes under the head of "Renr-guard Actions," and as the possible withdrawal of guns would not be a question of the first consideration when taking up your position, I passed that part of the subject over so as to have more time to discuss matters which are less clearly understood, and of at least equal importance. I quite agree with what Sir fiedvers saicl about firing on the infantry of the attack, and I hoped I had mnde myself clear on that point; but, leaving other considerations out of sight, until the infantry of the attack, appenrs we have no target but artillery to fire at, and must perforce engage the hostile batteries. Therefore, the contest between the two artilleries, even supposing it to be an undesirable feature in modern battles, becomes more or less inevitable. But one of the things we in the artillery are taught, and, I believe, try to carry out as much as possible, is, that the moment the infantry of the attack shows itself in any large numbers it must be fired upon by every gun. It was by doing that, I think, that the great suc:ess of Gettysbury was gatined. The Confederates liad an immensely superior force of artillery, and if the Federals had attempted to engage them they would have been destroyed. But hey, as I have shown, withdrew from the unequal contest, and absolutely disregarded the artillery, and fired at nothing but Pickelt's division. I nm quite sure that was the proper course to take, and the victory of Gettysburg is to be altributed to its having been adopted.

The Chursux : -1 have great pleasure in asking you, gentlemen, to pass a vote of thanhs to Major May for his paper. It is a paper which gives one a great deal to think about, and $I$ atm sure we all of us agree with his final paragraphs, where he shows plainly how important it is for artillery to have every possible opportunity of studying that most difficult of all problems-the best manner of keeping up the supply of anmunition.

Major Mlay's paper was afterwards read before the Military Society of Ireland at Dublin, on February 16th, 1899, Field-.Iarshal Lord Roberts, K.I'., G.C.B., G.C.S.I., G.C.I.E., Commander-in-Chief of the Forces in Ireland, being in the Chair, when the following discussion took place:-

:3:! Major-General M. W. E. Gosset, C.B., p.s.c. (Commanding Dublin Distric1):- When we hear so able a lecture as that delivered by Major May, it rather cuts the ground from under our feet, because he leaves nothing for us to criticise. Moreover, it is very difficult for an infantry officer to criticise so able an exponent of the subject of artillery, as Major May uncloubtedly is. He has incidentally toucaled upon one or two points which bear upon combined action of the three arms represented by artillery, cavalry, and infantry. And I think I may say that the one great value of this very interesting lecture to me, as an infantry officer, and I think I may say to all infantry officers, is the pointing out how necessary it is for all bodics, both cavalry, infantry, and artillery, to know the working of the different arms to which they do not happen to belong. It is a matter of which quite enough is not thought in our Service, at least as far as my experience has taught me. Atd although the synopsis for examinations in the Queen's Regulations at the present day lay's down pretty clearly that officers are obliged to study the combined action of the three arms of the Service, still we do not begin to acquire that knowledge early enough, and as a result it is confined very much to senior captains and majors. Therefore, you will observe that they do not begin to study until they have got on pretty well in the Service. With regard to artillery, I would like to make just a few remarks as to my experience of the working of that arm of the Service in manouvres. I had the advantage, when stationed at Bangalore, where I was in command, to have had three batteries-one horse and two field 
batteries-with the force which was quartered there. And in the small manouvres we had, I made it a point to take the command of batteries from the majors and captains, and to give them occasionally to the subalterns under them. These subalterns were very excellent men-very smart. officers. But when they got command of their batteries, it was a most extraordinary thing to find what dreadful mistakes they made-mistakes you would hardly expect that an infantry officer would make who studied the subject at all. I remember on one occnsion I gave a subaltern command of a battery in an attacking force. He came into position, but changed it in about a quarter of an hour, and then changed it again, quite forgetting that during.that time he was being ralied by the enemy's artillery. Many other faults were committed, such as putting wagons in a position where the shells which missed the gunners and the battery would undoubtedly fall upon the wagons, and the men round about them. This led me to belicre what an excellent thing it is for young officers to get a chance, even in a small way, of commanding the units to which they belong. I think, if there is a fault in our excellent artillery, it is to be found in the fact that the major, who is everything, is a little too much; that is to say, he takes everything under his command. He works up his battery, but he does not, perhaps, teach his subordinate officers enough. I therefore bring this matter forward as a criticism on the paper, being a thing worthy to note, and which I am sure Major May will be glad I should mention. I have no doubt that we have got to learn a great deal of what smokeless powder will do in the future, and in that connection I think the question of an advance post in front of a position may be altered to a certain extent. Major May, in the course of his lecture, remarks that we never use a counter-attack in our mancurres, which is no doubt very true. But, ats he very justly states, it is because that when the attack is once dereloped we rush it to such an extent that there is no time for a counter-attack at all. We might now very well consider the ques tion of an advance position with our smokeless powder, which would oblige an enemy to open at a distance, and also to attach guns to it to give it further power; and if we want to make a counter-attack, that it would be a very good point to bring the force up to with which you make the counter-attack. As regards the breaking up of brigade divisions, that is an artillery question about which I have not got much to say. But I have always noticed that the commander of a brigade division is extremely anxious to keep them together under any circumstances. Major May brings the practical question of breaking up brigade divisions before us, and he gives an example of how the breaking up of brigade divisions is very essential in mancuvres. There is no doubt about it that in a foree awaiting attack, you might with advantage break up a brigade division, provided always you could manage to keep some sort of control over it; and in these days of inter-communication by telegraphing, signalling, and other means a good deal might be done in that connection. With regard to the limit of range, that is a question which depends on how far you can see; though I doubt whether you can count upon anything beyond 3,000 yards. Prince Kraft, with his 3,400 yards, seems to ignore the fact that even if you can see at that distance you cainnot judge the result of your fire, and it is, therefore, a question of range vision more than the range of your gun. I may, perhaps, mention that in the Cape Kaffir War I had some curious cxamples of miscalculation of ranges, and though in that wonderfully clear climate you can sce exceedingly far, the distances are always very deceptive. A battery opened fire upon the enemy in the bush one day. I happened to be far away on the flank, but I could see quite plainly the shells bursting about 2,000 yards off. The range was calculated in that clear atmosphere as at 2,500 yards, but it was proved afterwards to be no less than 4,500 yards, which shows how difficult it is to judge your ranges in different climates. As regards Colonel Wille's-of the Swiss Army-idea, when he says that the artillery attack would direct its fire on the infantry right away, he assumes that long before the fight begins-that is, the infantry fight begins-the 
whole defence would be in position. That is a mistake we bave to guard against. Because my experience of the manceuvres generally has been, that if an officer is ordered to select a point for defence, or to await attack, as Major May very properly called it, he digs his trenches, he gets his men into position, he gets a sort of sign-post to fire at, and the enemy may perhaps attack him in another direction. The result is, that he has to re-assemble his forces, and the whole thing results in a jumble. Make your dispositions for defence, think how you would attack then if in the enemy's position, and do not occupy trenches by men before they are wanted. In the same way, the guns would be kept concealed until they were required. These are all the remarks I have to make on the subject of Major May's very interesting lecture.

Colonel C. F.C. BERESFord, R.E., p.s.c. (Chief Engineer, Ireland) :-There is a short paragraph in the introductory part of the paper, which we have just heard read by Major May, which appeals to me specially as an engineer officer, because what it states applies to the technicalities of the engineer service just as much as it does to those of the artillery service. The lecturer has spoken of the necessity of combined tactics, and how the staff, generals, and other branches of the Service should have a good knowledge of the working of artillery. I hope I shall be excused if I read to you this small paragraph :-"An arm which prides itself merely on technical knowledge and skill, and, because of its supposed technicalities, is not confidently handled by an officer alien to its ranks, will always be imperfectly understood, may even itself become prone to find excuses, and create impossibilitics." Now, I should like to draw a moral from that paragraph. The lecturer spoke on the subject of the knotty question of breaking up brigade divi-. sions cluring the fight, and he told us how an artillery commander may find his batteries disseminated on a long front, and how his whole thoughts would be taken up by planning the way in which to bring control of fire, and direction of fire, under one will. And he further told us that it is absolutely necessary that this control should be brought under the command of the higher artillery officer. But all this means that efforts are to be made to bridge over time and space. I only know of one agent that can properly bridge over time and space, and that is the field telegraph. I was for many years attached to the telegraph battalion at various stations, and I think I know pretty well from experience what the field telegraph can do, and what it cannot do. When I was at Aldershot I was con. stantly advocating the adoption of the fisld telegraph for tactical purposes, but I made nogreat progress in that effort, sinply because its technicalities were not understood. except by the officers and those who were actually working with it. I could not persuade the staff or general officers to work it at manouvres to the cxicnt I should have liked to have seen it used. But I feel confident that if the field telegraph was called on for any tactical purpose whatever, it would be found perfectly equal to the occasion. I always advocate in writing and in lectures at Aldershot the use of the field telegraph. But I wish elearly to be understood as to the position I take up, namely, that the field telegraph for other arms of the Service could not always be drawn from the telegraph battalion. The telegraph battalion worked by the engineers will always have its hands full with the lines of communication, and, therefore, what 1 advocated was the employment of regimental field telegraphs, so that every unit should have a regimental telegraph of its own. For instance, if the artillery had an equipment of its own, if such an equipment was attached to a brigade division, it should be entirely in the hands of the officers commanding brigade divisions during peace and war; and, as a consequence, I feal quite sure that very great progress would be made in the tactics of the artillery. In conclusion, I would ask the lecturer whether he has ever considered the subject of the field telegraph, and whether he has ever had any experience either at home or abroad of its being used for this tactical purpose.

Colonel W. G. Krox, C.B., R.H.A.:-A lecturer always in his lecture, in my opinion, refreshes our minds very much in history. And 
-on this"occasion, Major May stated at the opening of his lecture, that we hitherto have always fought on the defensive, and that our future battles will also be fought on the defensive. Well, I must say, that we get simply flooded with the attack formation, though we never, to my mind, half think about defensive formations at manceuvres. The lecturer has spoken very much about the massing of guns, but I think he has rather overlooked the fact that in our Service we miss a very important part of our training by not having smokeless powder in use during peace mancurres. And, perhans, I may he allowed to give my cxperience of what use foreign nations make in their trainings and tactical formations as far as artillery is concerned, by having smokeless powder. I must say it is the very gravest and most serious accusation that one can make against our arsenals and their directors, that they do not furnish us with smokeless powder. No doubt they have tried cordite, but there is no reason why we should not have some other species of smokeless powder than cordite. 1 was present during the manouvres in Germany. in 1897 , where the largest manocurres took place that have ever been held in that country, and possibly the largest that may ever be held there. There were four ariny corps at work, two on each side. My first day's expericnce of them was very interesting indeed. I heard the sounds of guns away in the distance. It was a dull, dark day, and I could not, therefore, see the guns any where, but I could hear them. However, with great difficulty I found them, but it was not until I was 900 yards off that I saw them. They were posicd in front of a wood in sone thick brushwood. I could see occasional fashes, but I could not detect the number of guns, and, to $\mathrm{my}$ extraordinary astonishment, when I got up to where they were, I found these guns were assisting a counter-attack. There were sixty guns on a front of 300 yards; that is to say, 5 yards a gun, all being utuder the direction of one man. When you see those large forces at work: you do not narrow your-mind to a brigade or a division, as they all appear to be working thoroughly easily. This cxperience opened my eyes immensely. In our Drill-Book I find only a front of eighteen guns is allowed or is mentioned, so you can imagine the contrast. The next day, the force on one side had to take up a defensive position to await an attack, very much as Major May describes it, from the complete force on the opposite side. It had to await an attack with two army corps, minus two divisions, waiting in position the arrival of a force to complete its position. I rode along the whole position, which was about $\bar{j}$ miles in length, broken in front by two villages. I was very much interested to know as to whether the villages through which I rode were' to be occupicd as advance posts. The iden of advance posts seemed to have vanished entirely. With regard to entrenchments thrown up, they dug a line of them, and small posts of entrenchments werc dug which were occupied by infantry, covered in by ground. Works were thrown up for batteries, for guns, at closest interval, only at such position where it was necessary for the guins to run forward to cover at right angles the dead ground where expedient. The troops did not occupy the position as a whole, but they were heid by a thin line of shirmishers. The troops themselves were in column in rear, on the reverse side of the hill, so that they were ready to man the entrenchments where necessary, or to form en masse on the flank for counter-attack. That is the principle upon which this line of defence was occupied. I must tell you that the normal distance occupied by foreign guns as compared with ours is very much in their favour. They learn with smokeless powder to drill very much closer than we do. Our eighteen guns would be met on the same line of front by twenty-four French or twenty-four German guns. The Germans even run up to thirty-four guns -they allow that in their drill-books. That is a very serious question, and as there is no doubt that our men, as far as organisation goes, are pounds better than eitherFrench or Germans, there is no reason why they should not drill up to that form. Major Mlay remarked about guns being under the command of supreme authority, 
and of being taken away from their units. He also alluded to the French manceuvres of 1897. I was absolutely present on the very day that Major May describes. With regard to the guns being put under the command of suprem? authority, I happened to have the orders of the French commander on the one side, who was commanding two army corps, which were attacking one. He got his opponents on the hop, and he went to follow them with his advance guard, which he told off from each army corps. He put the whole of bis artillery with the advance guard. He meant to keep his opponents on the hop, as I might say. Now, gentlemen, whatever kind of tactics we might enploy for the defence or for attack, the keynote of the whole thing is that drill leading up to combined tactics must be based on simplicity, and that must begin with the individual. But I must say, in our Service we do not fulfil the desired simplicity. I was looking this morning at the manual for rifle exercises, and $I$ find that there are no less than forty-two different way's of handling a rifle in our Service; and I looked at the Germans, and found they have only three. That sounds to me very strange, and appears as if something might with advantage be knokled out of ours. These different ways of handling a rifle do not include the funeral exercise. It is just the same with our cavalry. There is one word the lecturer made use of, and I do not quite understand why. He states, "Artillery in conjunction with a force awaiting attack." I cannot understand why he used the word "coijunction," and that instead he did not use the word "combination." We in our Service seldom act in conjunction, because we are not organised in conjunction. But we have a glorious heritage from our national games which goes to show the force of combination, and no better examples could be given than the games of polo and of football. We have in this country now, thanks to your Lordship's exertions, an opportunity of carrying out combirred tactics on a very superior scale, and that to my mind is field-fring. It is about time that infantry officers and artillery with their live shot and shell should work together. We have now a large tract of ground where field-firing can be carried out, and I think that if, instead of going to manceurres, we went there with our ammunition supplies, and with our picks and spades and shovels, and occupied defensive positions such as Major May has described in his lecture, and then attacked them, I nust say the benefit to us would be much better than going to the ordinary peace mancuvres.

Major MaY, in reply to the observations made on the lecture, said:Colonel Brooke has written to me a letter which I shali read; after a few preliminary remarks of a flattering character, he states:-" The lecturer does well to dwell so emphatically as he does on the importance of training in the renewal of ammunition, for the greater the expenditure becomes the greater the necessity of having personncl to work its replacement. It is, to my mind, waste of time bringing up batteries to form ammunition columns, for the officers and men thus drawn may belong to batteries required for fighting when the pinch comes. And I agree with the lecturer, that at the recent manceurres, the effort to represent these columns was merely clothing a skeleton in uniform. Let us hope that before the next big mancuvres we may have advanced a little towards replacing the skeleton by something more tangible, and calculated to give proper experience of ammunition supply on active service. I think the system is being thoroughly thought out. I regret to find the lecturer referring to the getting rid of ammunition. To speak of ammunition as being got rid of, is calculated to give rise to misconception, for I agree with the lecturer that our officers would be as capable of controlling the promised increase, as they are that of the present supply to the guns. I am sure the lecturer used the expression inadvertently. It seems doubtful to echelon guns for attack on the flank. By doing so you must sacrifice flank fire to mect flank attack, but even then the battery or batteries have to meet the flank attack. Would it not? . . . . . . I hardly think the lecturer has made it clear that once the infantry attack, the artillery must devote all its fire to it, just as Hunt did at Gettysburg. The Confederate artillery was 
entirely disregarded there, though the latter had a preponderance of guns, almost amounting to two to one. A better example could not be guoted to show to the artillery the value of what the lecturer, hardly, to my mind, has laid enough weight upon." Gentlemen, with regard to that, I am sorry I used the words "Got rid of"; it was merely accidental-any other words would suit as well. As regards accentuating artillery turning on the infantry of the attack, I really thought I had done that, because I said that there were only two great principles which never varied. One was that the officer commanding the artillery was to think where his opponent would go to next; and the other was that whenever the infantry attack appeared, every gun was to be turned upon them. As to echeloning guns on the flank, that is really a matter of circumstances and of degree. As regards what General Gosset said, I must thank him very much for his very kind remarks, because I think his criticisms were very valuable indeed. I think very likely he is right that we majors do not give our subordinates enough chance. But the reason of that is, because we know by practice a great deal depends upon us, and therefore we lake every opportunity of teaching ourselves. However, that has been noticed, and now when a battery goes to practise, they make casuals, as they call them, command; and it is quite a conimon thing for a battery to be commanded by a subaltern. In fact, two years ago at Aldershot they carried it to such an extent that we had a telegram from one of the officers stating that a battery had been brought out of action by the master tailor. As regards the long ranges, I quite agree with you, Sir. I look upon 3,000 yards as quite an extraordinary range. I referred to them simply to show that on the defensive you are governed by different ideas than in the case of attack. As regards the field telegraph, the subject was mentioned to me one day at Aldershot of putting the artillery in connection with it. My impression is that a brigade division would be too small a unit to have a field telegraph attaclied to it. But I think where you have very large numbers of guns, as in the case of an army corps, you might use it. I think Colonel Knox's remarks were very valuable. I used the word "conjunction" merely because it seemed to me much the same as combination, and $I$ thought it sounded a little better.

The Cirarmax (Field-Marshal Lord Roberts):-Major May has delivered a very interesting lecture on the part played by artillery acting-I won't say in conjunction-in combination with a force awaiting attack. And he has explained that this is a phase of war which is not often discussed, but I certainly think it is a very important pliase of war, and more especially is it so for officers belonging to a small Army like ours, which Major Nay has stated has so very frequently been required to act on the defensive, for a time, at any rate. But I noticed throughout his lecture, he does not refer in any way to what we call a passive defence; but he rather refers us to the case of an officer taking up a position, with a determination to make a counter-attack on the first favourable opportunity presenting itself. This officer decides that he can await attack, because he thinks that, although his force is so much inferior in numbers, the position he has taken up will compensate for that inferiority. He has had time to study and to improve his communications in the first place; so much so, that it enables him to bring up troops on any threatened point without suffering any very severe loss. He has also had time to study the ground in front of the position, which would warrant his mancuvring with a certain portion of his small force, with the object of delaying the enemy as long as possible. And he has had further time, also, to calculate the ranges of all points where the enemy's guns might, probably would, be placed. Now, these are very great advantages, and if properly utilised would certainly justify an officer deliberately awaiting to be attacked by a much stronger force. But Major May has explained to us that no skilful officer would be satisfied with merely acting on the defensive; he would appreciate that the counter-attack is the soul of the defence, and from the first, irrespective of the inferiority of his force, he would lay his plans for that counter-stroke, and he would dispose of his 
troops so that every man, horse, and gun would be available for the supreme cffort, and for the subsequent pursuit, provided that the counter-attack proved successful. Major Mlay has not referred, I notice, in the lecture to the pursuit, but I feel sure that so close a student of military history has not overlooked the fact that victory would not be complete by a counter-attack alone, unless it was followed up by a pursuit. General Gosset has referred to the question of the splitting up of brigade divisions of artillery. No doubt, as a rule, it ought not to be so, and that is what we are now organising our artillery in brigade divisions for. But the instance given by the lecturer is a very clear proof of how necessary it is at times to adopt other tactics than those laid down in the Drill-Book, and to be prepared as the circumstances of the moment may require. You will observe, also, that Major May laid stress upon the necessity of guns, being in a defensive position, not opening fire upon small parties of cavalry, or of shirmishing bodies coming on in front. It is really well worth bearing in mind, because the longer you can keep the enemy in ignorance of the defensive arrangements, the more chances there are of his committing some error in the disposal of his troops for the attack. The only other point I need mention is with reference to the stress which Major May lays on the word "conjunction" of artillery with other arms in a defensive position. The word which Colonel Knox uses is the "combination" of artillery with other arms in a defensive position. The commander having the choice of his position ought to be able to use his three arms in co-operation, which is much more difficult in an attack, for when the position is going to be assaulted, as you may have seen, no doubt, at the very decisive moment the infantry is almost certain to mistake the fire of its own guns. That is a matter which is very difficult indeed to avoid, but you must try to get rid of the difficulty as much as you possibly can. Major May refers to junior officers being given command of their respective units, which I believe would be most advan: tageous. With regard to the field telegraph, it would appear most difficult for an artillery unit, like a brigade division of artillery, to be hampered with field telegraph equipment ; but I think in a defensive position it would be an admirable thing for a commander to have at his disposal a field telegraph, but I do not think you could manage it with small units. Colonel Knox spoke about the use of smokeless powder; well, all I can say is, that that is really a matter of money, but I suppose we shall get it when our present supply of powder is used up. I do not think 1 need take up your time with any further remarks. We are all very grateful to Major May for coming amongst us to-day, and I am sure you will all wish me to convey to him our very sincere thanks, not only for the subject of his lecture, but for the very intelligent manner in which he has delivered it. 